\title{
Identification of arid phases during the last 50 cal. ka BP from the Fuentillejo maar-lacustrine record (Campo de Calatrava Volcanic Field, Spain)
}

JUANA VEGAS, ${ }^{1 *}$ BLANCA RUIZ-ZAPATA, ${ }^{2}$ JOSÉ E. ORTIZ, ${ }^{3}$ LUIS GALÁN, ${ }^{4}$ TRINIDAD TORRES, ${ }^{3}$ ÁNGEL GARCÍA-CORTÉS, MARÍA J. GIL-GARCÍA, ${ }^{2}$ ALFREDO PÉREZ-GONZÁLEZ ${ }^{5}$ and JOSÉ L. GALLARDO-MILLÁN ${ }^{6}$

${ }^{1}$ Instituto Geológico y Minero de España (IGME), Madrid, Spain

${ }^{2}$ Departamento de Geología, Facultad Ciencias, Campus Universitario, Universidad Alcalá, Madrid, Spain

${ }^{3}$ Laboratorio de Estratigrafía Biomolecular, ETSI Minas, Universidad Politécnica Madrid, Madrid, Spain

${ }^{4}$ Instituto Geológico y Minero de España (IGME), Madrid, Spain

${ }^{5}$ Centro Nacional de la Evolución Humana, Burgos, Spain

${ }^{6}$ Departamento de Ingeniería Geológica y Minera, Universidad Castilla-La Mancha, Ciudad Real, Spain

ABSTRACT: Geochemical (element analysis, molecular analysis of organic compounds), physical, palynological, mineralogical and sedimentary facies analysis were performed to characterise the sedimentary record in Fuentillejo maar-lake in the Central Spanish Volcanic Field of Campo de Calatrava, in order to reconstruct the palaeoenvironmental and palaeoclimatic processes which controlled vegetation patterns and deposition of different sedimentary facies. The upper $20 \mathrm{~m}$ of core FUENT-1 show variations in clastic input, water chemistry, vegetation and organic fraction sources in the lake throughout the Late Pleistocene and Holocene. The temporal framework provided by ${ }^{14} \mathrm{C}$ accelerator mass spectrometry dating allows assigning the sequence to the last $50 \mathrm{cal}$. ka BP. Arid phases identified in the FUENT-1 sequence are correlated to Heinrich events (HE) and to stadials of the Dansgaard/Oeschger (D/O) cycles. Siliciclastic facies with high magnetic susceptibility values, high Juniperus pollen content, a low Paq index (aquatic macrophysics proxy index), a decrease in the relative percentage of the $n-C_{27}$ and an increase in the $n-C_{31}$ alkanes are indicative of arid and colder climatic events related to HE 2, HE 1 and the Younger Dryas (YD). Similar short cold and arid phases during the Holocene were identified at 9.2-8.6, 7.5-7 and 5.5-5 cal. ka BP. In dolomite-mud facies, the pollen data show an increase in the herbs component, mainly - Chenopodiaceae, Artemisia and Ephedra - steppe taxa; a low Paq index, a decrease in the relative percentage of the $n-C_{27}$ alkane and an increase in the $n-C_{31}$ alkane are also observed. This facies was probably the result of lower lake levels and more saline-alkaline conditions, which can be interpreted as linked to arid-warm periods. These warm and arid phases were more frequent during Marine Isotope Stage (MIS) 3 and the interstadials of MIS 2. HE 4, HE 2, HE 1 and the YD in core FUENT-1 were immediately followed by increases of warm steppe pollen assemblages that document rapid warming similar to the D/O cycles but do not imply increasing humidity in the area. Fuentillejo hydrology is controlled by changes in the atmospheric and oceanic systems that operated on the North Atlantic region at millennial scale during the last $50 \mathrm{cal}$. ka BP.

\section{Introduction}

Marine and ice core sequences provide the reference records of Quaternary climate variability but it is still unknown how these changes correspond to events on land over long distances and lower latitudes because of a shortage of suitable terrestrial sequences and inadequate chronological control (Tzedakis et al., 2006). In some exceptional circumstances, favourable geological conditions have led to the relatively undisturbed accumulation of thick sedimentary lake sequences, some of them located in the European Mediterranean realm (e.g. Florschütz et al., 1971; Tzedakis et al., 1997; Allen et al., 1999; Ortiz et al., 2004, 2006). A few terrestrial sequences covering the entire last glacial and previous glacial periods are available on the Iberian Peninsula (e.g. Pons and Reille, 1988; 
Montserrat, 1992; Burjachs and Juliá, 1994; Carrión et al., 1998; Gómez-Orellana et al., 2007; Schulte et al., 2009), but most continental climate and vegetation changes in Iberia have been inferred from marine cores. In these studies, the pollen content of marine sediments is frequently used to reconstruct the continental climates in the westernmost Mediterranean (Combourieu-Nebout et al., 2002; Sánchez-Goñi et al., 2002; Baudin et al., 2007) and the lberian margin (Sánchez-Goñi et al., 1999, 2000; Boessenkool et al., 2001; Roucoux et al., 2005) and reveal that arid and cold conditions occurred during Heinrich events (HE) and some cold stadials. On the Iberian Peninsula, palaeoclimatic records obtained from a wide range of marine and terrestrial archives document rapid fluctuations during the last glacial and provide evidence of the so-called Dansgaard/Oeschger (D/O) cycles and HE cold events in this area (Cacho et al., 1999, 2000, 2006; Moreno et al., 2002, 2005; Valero-Garcés et al., 2004; González-Samperiz et al. 2006; Bout-Roumazeilles et al., 2007). These studies of millennial-scale changes, based mainly on pollen and stable isotope analysis and alkenone data, have demonstrated that this region was very sensitive to rapid climatic and oceanographic glacial variability described in the North Atlantic region, showing that its climate is closely coupled with the oceanatmospheric system.

In 2002, a $142.4 \mathrm{~m}$ sediment core (FUENT-1, Vegas et al., 2004) was drilled at the central part of Fuentillejo maar-lake to investigate the potential of this lake as a record of millennialscale palaeoclimatic changes which have occurred in central
Spain over the Quaternary. This record constitutes one of the best examples of long and continuous terrestrial deposition during the last $50 \mathrm{ka}$ (uppermost $20 \mathrm{~m}$ ). In order to understand the links between the cold-arid climatic events in the Greenland ice core (Johnsen et al., 1972, 1992) and the climatic changes over the West Mediterranean basin recorded in Alboran marine cores (Cacho et al., 1999, 2000; Moreno et al., 2002, 2005; Sánchez-Goñi et al., 2002; BoutRoumazeilles et al., 2007) and over central Spain, highresolution geochemical (element analysis, molecular analysis of organic compounds), physical, palynological, mineralogical and sedimentary facies analysis of sediments from the FUENT-1 core were performed on this $0-50 \mathrm{ka}$ interval.

\section{Area of study}

The study site is located in the south-west of Valverde de Calatrava (Ciudad Real), in the area known as Campo de Calatrava Volcanic Field (CCVF) in the Central Volcanic Region of Spain (Castilla-La Mancha district) (Fig. 1). The volcanism of CCVF was developed in at least three stages. The first one, of ultra-potassic character, occupies the centre of the volcanic region and has an age ranging between 8.7 and $6.4 \mathrm{Ma}$. The second stage was characterised by alkaline and ultra-alkaline volcanism, with a main activity phase between 4.7 and $1.75 \mathrm{Ma}$
(A)

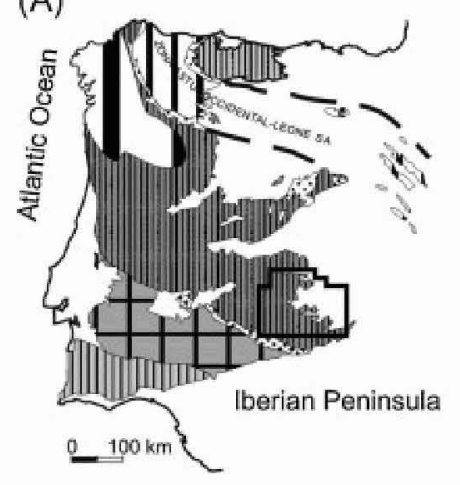

(B)

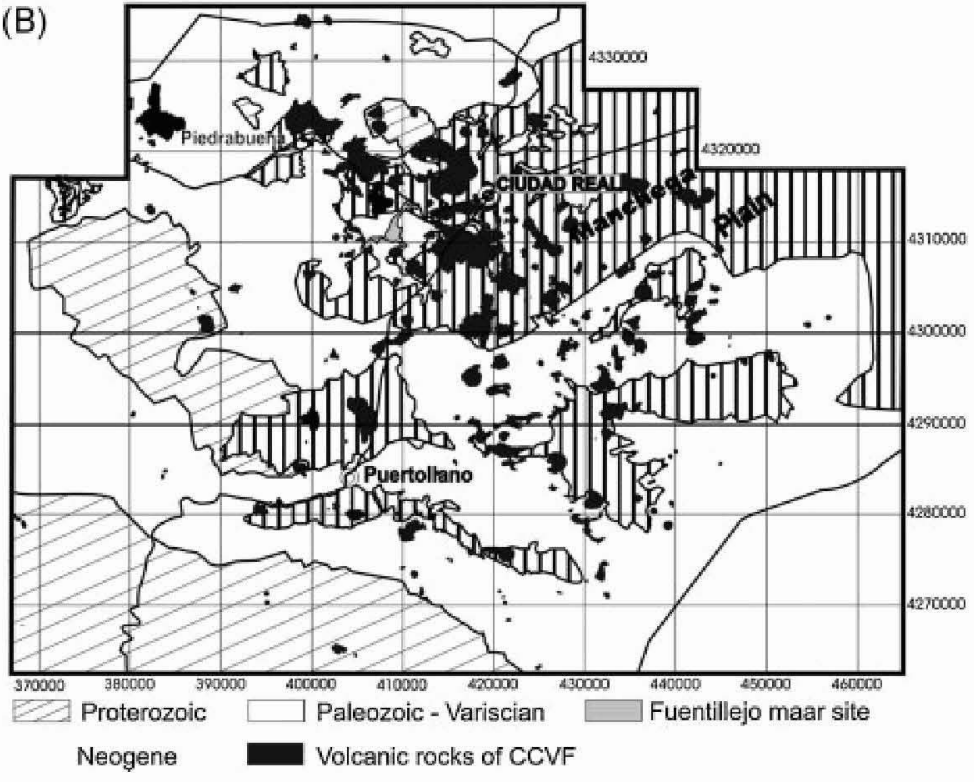

(C)

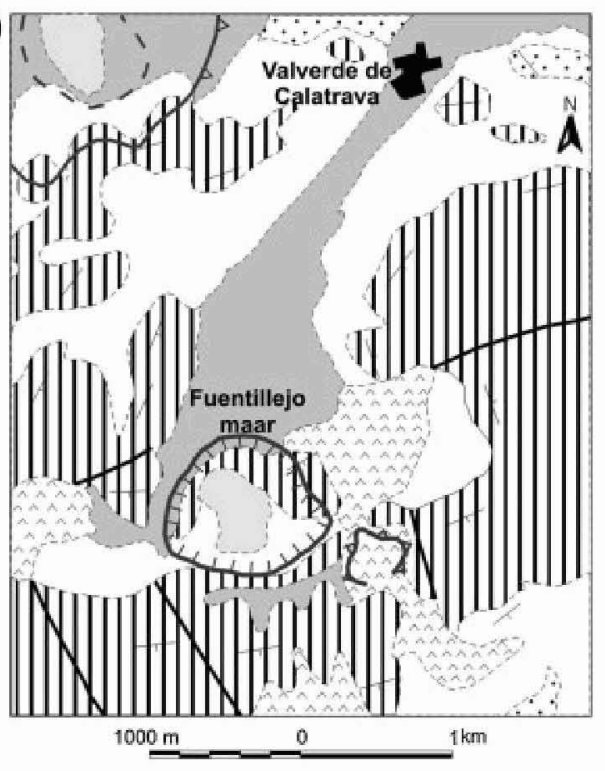

Silts and clays. Playa-lake deposits

Gravels, sands and clays, Alluvial fans-colluviums (Pravistocisene)

Hydromagmatic deposits

Nefelinites (Pliocene)

$\because$ Limestones and marls (Pliocene)

Quartzites and slates (lower Palaeozoic)

Structural and geomorphological signs

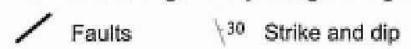

Mars on metamorphic rocks (9) Maars on

Figure 1 (A) Location map of the study site on the Iberian Peninsula. (B) Simplified geological map of the Campo de Calatrava Volcanic Field (CCVF) (Gallardo-Millán, 2004). (C) Geological map of the Fuentillejo maar site, Ciudad Real province (simplified from Portero et al., 1988) 
(Ancochea, 1983; Bonadonna and Villa, 1984). Later, volcanic activity occurred in the Early Pleistocene, greatly expanding the period of volcanic activity in the region, between $1.3 \mathrm{Ma}$ and $0.7 \mathrm{Ma}$ (Gallardo-Millán and Pérez-González, 2000; GallardoMillán et al., 2002; Gallardo-Millán, 2004). The regional climate is Mediterranean with a strong continental influence (Font-Tullot, 1983, 1988; Fernández-García, 1986). It is characterised by hot summers and cold winters, and an average annual temperature of $14.5^{\circ} \mathrm{C}$. Average annual rainfall is about $391 \mathrm{~mm} \mathrm{a}^{-1}$, although inter-annual variability is large. In La Mancha semi-arid region the evaporation rate is of $1400 \mathrm{~mm} \mathrm{a}^{-1}$ (Ordoñez et al., 1994). March, April and June are the wetter months, and July and August are the driest (average summer rainfall $32 \mathrm{~mm}$ ).

The explosive volcanic processes which produced the Fuentillejo maar (38 $56^{\prime} 22^{\prime \prime} \mathrm{N}, 4^{\circ} 3^{\prime} 13^{\prime \prime} \mathrm{W}$ ) affected Tremadocian-Arenigian slates and quartzites (Fig. 1), forming a crater of round morphology. The main characteristic at the north morphology is a maar surrounded by a tuff ring (height difference of $40 \mathrm{~m}$ ), while the southernmost part is marked by a quartzite wall of more than $120 \mathrm{~m}$ in height. The explosive processes also produced a pyroclastic surge deposit that lies unconformably on the Palaeozoic and Pliocene rocks of the region. The maar has an internal diameter of $450 \mathrm{~m}$, an external diameter of $1400 \mathrm{~m}$, and contains over $142 \mathrm{~m}$ of lacustrine sediments (Vegas et al., 2004). Since its origin, the lacustrine basin has been a closed system, with three main alluvial fans that have provided siliciclastic (quartzitic rock fragments) and volcanic (nephelinite, basaltic and pyroclastic fragments) debris from the small watershed towards the basin. At present, Fuentillejo maar-lake is an ephemeral, small closed lake at $635 \mathrm{~m}$ above sea level (a.s.l.) and has a hyposaline water column ( $\mathrm{pH} 8.7$ and conductivity $2005 \mu \mathrm{S} \mathrm{cm}^{-1}$ ). The lake has no surface inflow or outflow. The most common ions present in the lake waters are $\left(\mathrm{mg} \mathrm{L}^{-1}\right): \mathrm{HCO}_{3}^{-}, 616 ; \mathrm{Na}^{+}, 384 ; \mathrm{Cl}^{-}$, $310 ; \mathrm{CO}_{3}, 36.36 ; \mathrm{K}^{+}, 41 ; \mathrm{SO}_{4}^{2-}, 27 ; \mathrm{Mg}^{2+}, 23$; and $\mathrm{Ca}^{2+}, 15$.

\section{Methods}

A borehole was drilled in 2002 to recover the $142.4 \mathrm{~m}$ lacustrine sequence know as the FUENT-1 core. Twenty-three major lithostratigraphic units have been identified in core FUENT-1 (Vegas et al., 2006), and reflect variations in clastic input, water chemistry, vegetation and organic fraction. Core sections were stored in a core repository at $4{ }^{\circ} \mathrm{C}$ and split into two halves by an electro-osmotic core-cutting device (Vegas et al., 2004). All discussion about correlation of different proxies studied is based on measurements carried out in the same sediment core and with the same sampling interval of $10 \mathrm{~cm}$, and is therefore effectively independent of the age model.

Palaeomagnetic samples were analysed the Paleomagnetism Laboratory (Jaume Almera, CSIC). Measurements of the natural remanent magnetisation were performed with a $2 \mathrm{G}$ SRM755R magnetometer with an alternating field demagnetizer D-Tech 2000 (ASC Scientific). Each sample box of $10 \mathrm{~cm}^{3}$ was demagnetised in 10-12 steps with maximum alternating field amplitudes of $100 \mathrm{mT}$. High-resolution determination of magnetic susceptibility (MS) and bulk density were performed on one of the core halves by means of an automated GEOTEK Multisensor Core Logger (MSCL) system in the Core Physical Properties Laboratory of the IGME (Galán et al., 2007). Measurements were performed at $1 \mathrm{~cm}$ increments, using a MS2E1 Bartington spot-reading sensor for MS determinations. The low field volume magnetic susceptibility (K) data are expressed as multiples of $10^{-5} \mathrm{SI}$ units and density as $\mathrm{g} \mathrm{cm}^{-3}$. Bulk geochemistry ( $\mathrm{Si}, \mathrm{Al}, \mathrm{K}, \mathrm{Fe}, \mathrm{Ca}, \mathrm{Ti}, \mathrm{Mn}, \mathrm{K}, \mathrm{Mg}$ and $\mathrm{P}$ ) of samples was determined every $10 \mathrm{~cm}$ at the IGME Laboratory by X-ray fluorescence analyses (MagiX PANalytical). Total carbon (TC), total inorganic carbon (TIC) and total sulphur content (S) were measured on an ELTRA CS-800 elemental analyser. Total organic carbon (TOC) was calculated by the difference between $\mathrm{TC}$ and $\mathrm{TIC}\left(2 \mathrm{~h}\right.$ at $\left.550^{\circ} \mathrm{C}\right)$. Analyses of mineralogical compounds were carried out by X-ray powder diffraction using a copper $K \alpha$-tube on a PANalytical XPERT Pro (PTE-RX-004). Authigenic minerals, particle morphologies and textural relationships were observed by scanning electron microscopy (SEM) at Luis Brú Microscopy Centre (Complutense University). SEM observations were performed with a JEOL JSM 6400 operated at $20 \mathrm{kV}$ and equipped with a Link System energy dispersive X-ray microanalyser (EDX).

Biomarkers were extracted following the Biomolecular Stratigraphy Laboratory (UPM) protocol, which consists of $24 \mathrm{~h}$ Soxhlet extraction with dichloromethane and methanol 2:1 (Suprasolv, Merck) and concentration of the isolated bitumen using a rotor-vapour device (Lucini et al., 2000). Samples were injected into an HP 6890 gas chromatograph with selective mass detector HP 5973 and HP-5MS column. The compounds were identified with the Data Analysis program and the Wiley Library. n-Alkanes were calculated from the GC/MS chromatograms of $\mathrm{m} / \mathrm{z} 57$.

Pollen analysis followed the standard procedure described by Coûteaux (1977), Moore et al. (1991) and Goeury and Beaulieu (1979), using the classical chemical treatment by HF, $\mathrm{HCl}$ and $\mathrm{KOH}$ with mineral separation in heavy liquid Thoulet by the Palynology Laboratory (Geology Department, Alcalá University) Pollen grains and spores were sampled every $10 \mathrm{~cm}$ in core FUENT-1, and extracted in the laboratory by the classic method (Moore et al., 1991) using Thoulet dense liquid (2.0) for palynological concentration (Goeury and Beaulieu, 1979). Residues were mounted in silicone oil. Pollen percentages for all palynomorphs are based on the sum of 300-500 terrestrial pollen types. The pollen sum excludes aquatic taxa, fern and algal remains (Birks and Birks, 1980; Moore et al., 1991). A pollen diagram was prepared using the TILIA ${ }^{\circledR}$, TILIA GRAPH ${ }^{\circledR}$ and TGVIEW software packages (C) Eric C. Grimm; Grimm, 1987). Sterile samples are represented in the pollen diagram as breaks in the pollen curves.

\section{Results}

\section{Age model}

Palaeomagnetic measurements performed along the length of the FUENT-1 core (Gallardo-Millán et al., 2008) provide a preliminary chronological framework for the core. A magnetic reversal at $140 \mathrm{~m}$ depth probably provides evidence of the Matuyama-Brunhes boundary for this level. Moreover, three possible polarity excursions were identified at $109 \mathrm{~m}, 71-60 \mathrm{~m}$ and $17 \mathrm{~m}$ depth, and are interpreted as previously described excursions within the Brunhes Normal Chron (Holt and Kirschvink, 1996; Hirokuni, 2005; Channell, 2006). These magnetic excursions are not always identifiable at other localities but they will provide a more accurate chronological framework for the Fuentillejo lacustrine record (Fig. 2).

Dating the sediments from Fuentillejo maar-lake is difficult due to the scarcity of terrestrial organic remains. Eleven ${ }^{14} \mathrm{C}$ accelerator mass spectrometric dates were obtained on bulk organic matter samples from the upper $19 \mathrm{~m}$ of core 


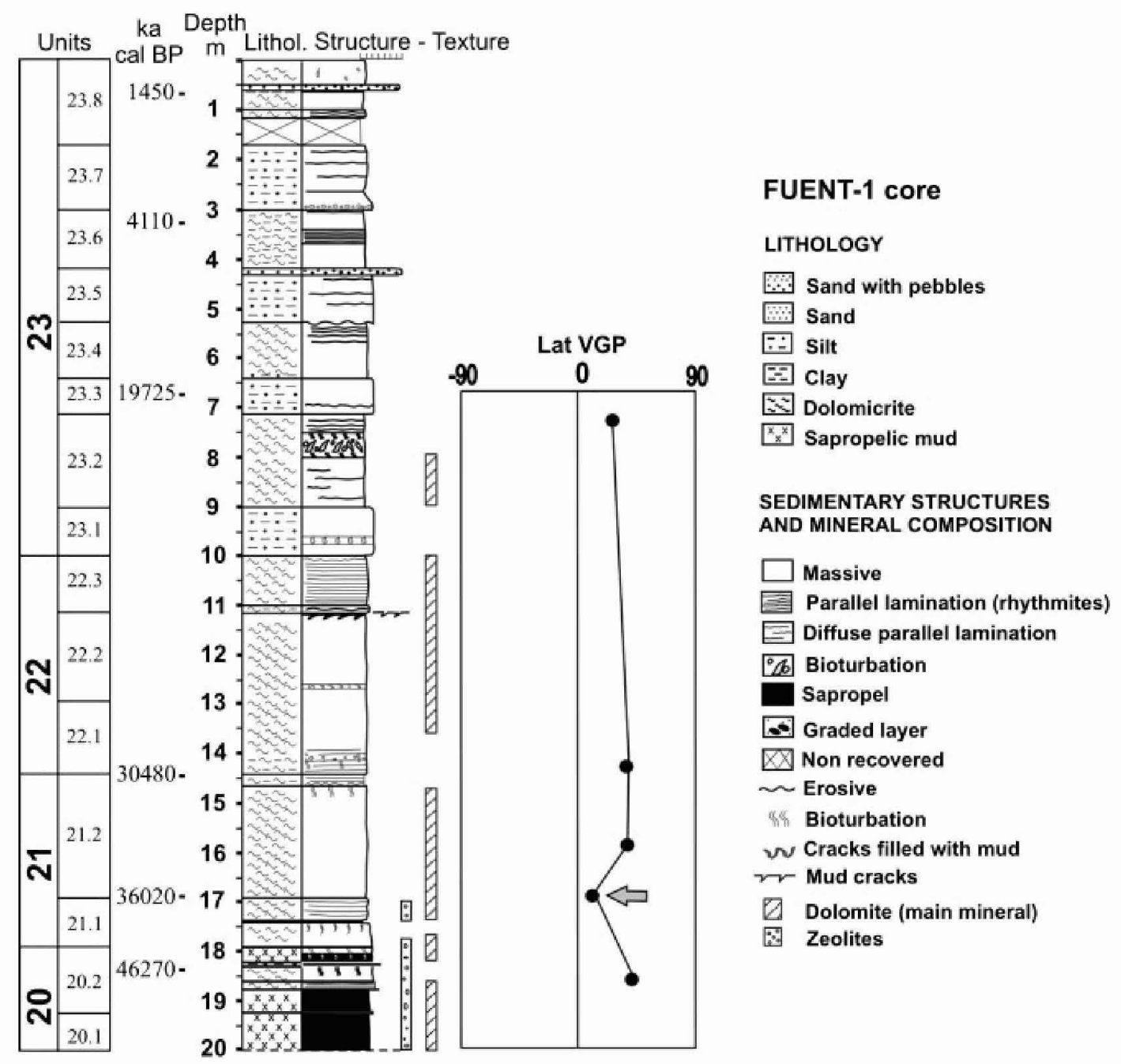

Figure 2 Stratigraphic column from top $20 \mathrm{~m}$ of the FUENT-1 core (Fuentillejo maar-lake, Ciudad Real). Calibrated radiocarbon ages and palaeomagnetic measurements (polarity) are included. Lat VGP, latitude of the virtual geomagnetic pole. A magnetic excursion is identified at $17 \mathrm{~m}$ depth which probably corresponds to the Mono Lake excursion (34-32 ka BP), within the Brunhes Normal Chron (Hirokuni, 2005). This excursion has a similar age to the calibrated radiocarbon age obtained in the same stratigraphic level

FUENT-1 (Table 1). Ages younger than $20 \mathrm{ka}$ were adjusted using the INTCAL04 calibration curve (Reimer et al., 2004) at $2 \sigma 95 \%$ probability. Older ages were calibrated using the CalPal 2005 software (Cologne Radiocarbon Calibration Palaeoclimate Research Package, www.calpal.de). Five dates are excluded from the final age model because their ages exceeded underlying younger ages and their stratigraphic setting suggested that these dates come from reworked material. An age model based on linear interpolation between median calibrated dates shows evidence for variable sedimentation rates over the span of this core.

\section{Sedimentary record}

The upper $20 \mathrm{~m}$ of the FUENT-1 core (Fig. 2) has been divided into four main lithostratigraphic units 20,21, 22 and 23 (bottom to top) that have been based on sedimentological, lithological and geochemical criteria (Vegas et al., 2006). These four units represent lacustrine sedimentation over the last $50 \mathrm{cal}$. ka BP. Facies B-E in the Fuentillejo sediments are carbonate-rich, while facies A is siliciclastic (Table 2). Unit 23 is the thickest and was divided into eight subunits which alternate between facies A $(23.7,23.5,23.3$ and 23.1) and carbonate facies B $(23.8,23.6,23.4$ and 23.2$)$. Unit 22 is mainly carbonate and is composed of subunits 22.3 (facies D) and 22.2-22.1 (facies C). Unit 21 is divided into subunits 21.2 (facies C) and 21.1 (facies E, D and C). Finally, unit 20 is mainly formed by facies $\mathbf{E}$.

\section{Continental aridity proxies}

Sedimentary facies - authigenic minerals - bulk density

Variations in lacustrine facies together with the presence of diagenetic minerals are effective environmental and climatic proxies. Sediment bulk density depends on the texture and mineral composition of the sediments. The FUENT-1 core bulk density primarily reflects mineral composition with low density values $\left(<1.5 \mathrm{~g} \mathrm{~cm}^{-3}\right)$ that are indicative of carbonate-rich mud and relatively higher TOC. High bulk density values $\left(>1.5 \mathrm{~g} \mathrm{~cm}^{-3}\right.$ ) correspond to higher contents of clay and silts enriched in quartz and siliciclastic particles. The absence of any significant carbonate rocks in the catchment suggests an authigenic origin for the carbonate minerals. Black sediments (facies E) in unit 22 are very poor in organic matter (very low TOC). Thus the black colour of these sediments is probably due to the presence of $\mathrm{Fe}^{2+}$ in the lattices of silicates or aluminosilicates (Castanier et al., 1993). 
Table 1 Radiocarbon ages of the Fuentillejo maar-lake core FUENT-1 sediments (Ciudad Real, central Spain). All ages were measured from the bulk organic fraction of core sediments

\begin{tabular}{|c|c|c|c|c|c|c|}
\hline Depth (m) & Sample & ${ }^{14} \mathrm{C}$ a BP & cal. a BP & Median cal. a BP & ${ }^{13} \mathrm{C} /{ }^{12} \mathrm{C}$ & \\
\hline 0.45 & Beta-215417 & $4030 \pm 40$ & $4580-4420^{\mathrm{a}}$ & 4500 & -22.9 & Reworked \\
\hline 0.65 & Beta-204449 & $1570 \pm 40$ & $1540-1360^{\mathrm{a}}$ & 1450 & -22.7 & \\
\hline 3.22 & Beta-215418 & $3750 \pm 40$ & $4240-3980^{\mathrm{a}}$ & 4110 & -23.9 & \\
\hline 4.35 & Beta-204450 & $15420 \pm 70$ & $18880-18000^{\mathrm{a}}$ & 18440 & -24.1 & Reworked \\
\hline 6.75 & Beta-190136 & $16540 \pm 90$ & $20240-19210^{\mathrm{a}}$ & 19725 & -24.3 & \\
\hline 8.40 & Beta-190137 & $27910 \pm 260$ & $33610-31130^{\mathrm{b}}$ & 32370 & -24.7 & Reworked \\
\hline 9.90 & Beta-190138 & $26070 \pm 230$ & $31220-30420^{\mathrm{b}}$ & 30820 & -25.8 & Reworked \\
\hline 12.07 & Beta-215419 & $33580 \pm 450$ & $41880-36320^{\mathrm{b}}$ & 39100 & -24.0 & Reworked \\
\hline 14.45 & Beta-190139 & $25470 \pm 210$ & $30860-30100^{b}$ & 30480 & -24.6 & \\
\hline 16.91 & Beta-190140 & $30880 \pm 360$ & $36780-35260^{b}$ & 36020 & -20.3 & \\
\hline 18.40 & Beta-177581 & $42620 \pm 1490$ & $49230-43313^{b}$ & 46270 & -22.2 & \\
\hline
\end{tabular}

${ }^{a}$ Calibration ages are $2 \sigma 95 \%$ probability, INTCAL04 (Reimer et al., 2004).

${ }^{b}$ Age calibration was made with CalPal software, version May 2005 , by $2 \sigma 95 \%$ probability (Cologne Radiocarbon Calibration Palaeoclimate Research Package, www.calpal.de).

Units 20,21 and 22 are mainly composed of blue and creamcoloured massive and slightly laminated carbonates (facies B and $\mathrm{C}$ ). Dolomite, calcite and zeolites (mainly analcime and minor chabazite-merlinoite) of primary or early diagenetic origin were identified in the FUENT-1 sequence. The presence of analcime and other zeolites in lacustrine sediments has been interpreted to reflect changes in the salinity and alkalinity of the lake water, induced by climatic shifts (Stoffers and Holdship, 1975; Singer and Stoffers, 1980). During the driest periods, corresponding to very low lake water levels, the concentration of salts in the water produced a brine with a sufficiently high $\mathrm{Na}^{+} / \mathrm{H}^{+}$ratio to allow analcime precipitation (Singer and Stoffers, 1980). These authors interpreted these occurrences as a drastic decrease in the lake water level associated with a climatic desiccation.

All carbonate phases are composed of euhedral crystals (2$10 \mu \mathrm{m})$, suggesting that they are precipitated within the lake. Dolomite (dolomicrite) formation of primary origin indicates evaporative processes, low lake level and higher salinity, and is probably linked to a more arid climate. Microcrystalline dolomite and related carbonate minerals usually form in shallow ephemeral alkaline lakes (von der Borch and Lock, 1979; Last and De Deckker, 1990; García del Cura et al., 2001) but dolomite also occurs in deep-water lake sediments (Last and De Deckker, 1990). They form in areas where evaporation rates exceed inflow rates and lakes become desiccated during summer months. More evaporation or less precipitation (arid period) would imply more concentrated waters and lead to precipitation of offshore carbonates (Moreno et al., 2007b). Moreover, carbonate-rich subunits with mud cracks, zeolites, relatively lower TOC, a low Paq index (aquatic machrophytes proxy index) and steppe taxa pollen assemblages (Fig. 3) are indicative of low water level in the lake, most probably reflecting arid phases and higher temperatures.

\section{Magnetic susceptibility (MS) $-\% \mathrm{TiO}_{2}-$ Total Organic Carbon} (TOC)

The mineral-magnetic properties of Fuentillejo maar-lake sediments are controlled by erosional processes and early diagenesis of iron-bearing minerals (Galán et al., 2007). Ferric oxyhydroxides are preserved during dry periods of low lake level associated with detrital sedimentation. Intervals with high MS generally consist of massive brownish sediments (facies A) characterised by low TOC values (Fig. 3) that occur in unit 23 (lower part of subunit 23.7; subunit 23.5; middle part of subunit 23.4; subunits 23.3 and 23.1). TOC content represents the fraction of preserved organic matter. These intervals represent oxic phases with good preservation of magnetite but severe degradation of organic matter. Because of the isolation of the catchment area, it is assumed that both the general composition

Table 2 Description of main facies identified in the upper $20 \mathrm{~m}$ of Fuentillejo lacustrine sequence (FUENT-1 core)

Facies Description and depositional environment

Facies A

Brownish to reddish massive clayey silts and no carbonate layers with very low organic carbon. Quartz grains, clay minerals (mainly smectite and illite) and volcanic rock fragments comprise most of the silicate fraction. Alluvial fan advance into a shallower lake

Facies B White to cream-coloured massive and banded carbonate-rich layers which are composed of dolomite and calcite $(2-10 \mu \mathrm{m}$ euhedral crystals) and minor detrital smectite. Relatively high organic carbon content. On occasions there is evidence of subaerial exposure (mud cracks) and remobilisation of primary sedimentary structures as bioturbations. Oxic bottom. Low lake level

Facies C Blue massive to slightly banded carbonate-rich layers mainly formed by dolomite (2-20 $\mu \mathrm{m}$ euhedral and rice-shaped crystals) and minor calcite. Organic carbon content is highly variable. Distal playa-lake. High salinity

Facies D Brownish to creamy fine mm-thick laminated carbonate-rich sediments with minor detrital particles (quartz and clay minerals). Low organic carbon content. Relatively deeper lake. Anoxic lake bottom Black massive carbonate mud layers where dolomite is the main component. Zeolites also occur as analcime and minor chabazite merlinoite. Clay minerals are absent and organic carbon content is very low. High salinity. Anoxic lake bottom 


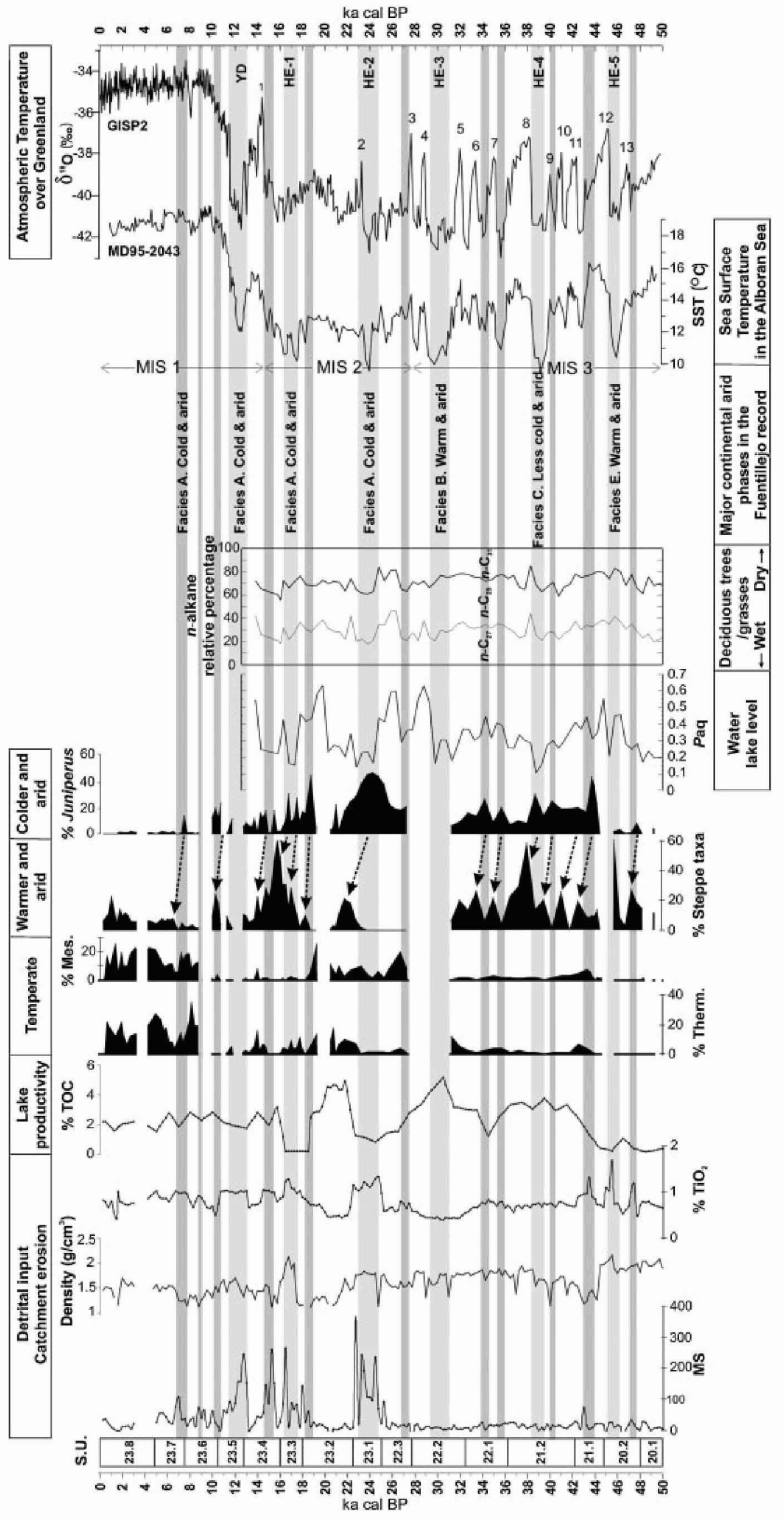

Figure 3 Selected proxies from the Fuentillejo sequence plotted against age. The $\delta^{18} \mathrm{O}$ from GISP2 (Grootes and Stuiver, 1997) and the sea surface temperature (SST) record from the MD95-2043 core (Cacho et al., 1999) are included for comparison. Interstadials are indicated by numbers. S.U., sedimentary units; MS, magnetic susceptibility $\left(10^{-5} \mathrm{SI}\right.$ units); TOC, percentage of total organic carbon; \%Therm., thermophilous taxa. \%Mes., mesophilous taxa. Dotted arrows indicate Juniperus-dominated phases that were immediately followed by increases of warm steppe pollen assemblages that document rapid warming similar to the $\mathrm{D} / \mathrm{O}$ cycles. Paq, values calculated as the $\mathrm{C}_{23}+\mathrm{C}_{25} / \mathrm{C}_{23}+\mathrm{C}_{25}+\mathrm{C}_{29}+\mathrm{C}_{31}$ ratio (Ficken et al., 2000). MIS, Marine Isotopic Stage. YD and HE events are indicated by light-grey bars. Representative D/O stadials in the FUENT-1 sequence are indicated by dark grey bars. Sedimentary facies description is included in Table 2 
and the amount of lithogenic fraction were supplied by alluvial fans and aeolian processes. This suggestion is confirmed by the contents of $\mathrm{TiO}_{2}$, a parameter regarded as one of the best proxies for lithogenic supply (Minyuk et al., 2007). Moreover, clay mineral analysis carried out along the FUENT-1 core has shown smectite-illite-kaolinite assemblages which originated from physical weathering coincident with high MS and Ti content.

Low MS from dilution of the lithogenic fraction by biogenic input occurred in sedimentary units 20 and 21. Pronounced low values in MS can be attributed to climatically induced reductive dissolution of magnetite in the deposited sediments (Minyuk et al., 2007). Anoxic phases of the lake led to a massive reductive magnetite dissolution but preservation of organic matter (Williamson et al., 1998; Nowackzyk et al., 2002). Sediments with low dry density and low MS indicate a more stable catchment, with less erosion of soils, and a lake with higher productivity. The interaction of deposition of organic matter and its preservation (or decomposition) under anoxic (or oxic) conditions, and the input of magnetic minerals and their depositional dissolution, suggests that Fuentillejo maar-lake can provide a detailed record of climate conditions.

\section{Pollen record: steppe taxa and Juniperus}

Around 50 pollen taxa of terrestrial origin, five pollen taxa of aquatic origin, spores and nine types of non-palynological microfossils (NPM) were identified in the FUENT-1 core. The different types of vegetation changes found in the lake sediments must be viewed within the context of their local environmental setting (Mediterranean climate with strong continental influence). Two main pollen assemblages are used to mark the main arid phases (Fig. 3): (1) the steppe to semidesert association, composed of Chenopodiaceae and Artemisia, are associated with salinity tolerance in the lake system, and Ephedra, which indicates drier and warmer climatic conditions; and (2) the cold steppe assemblage composed mainly of Juniperus. In the FUENT-1 pollen diagram, this taxon shows high percentages during cool intervals, reflecting the dryer and colder climate characteristics of central Spain. Juniperus was selected as a better indicator of rapid climatic changes than Pinus in the Pyrenees (González-Samperiz et al., 2006). The maximum percentages of mesic plants (deciduous Quercus and Corylus) associated with a reduction in steppe and Juniperus indicates warmer and the most humid episodes in the FUENT-1 sequence (Fig. 3).

Samples taken at 3.5-4, 4.7-5, 7.7-8.1, 10.9-12.5, 17.718.1 and $19.2-19.5 \mathrm{~m}$ exhibit very low pollen concentrations and the diagram therefore includes six areas barren in pollen (Fig. 3). These areas are related to the dolomicrite facies but, unexpectedly, some of those intervals show high TOC values so it is possible that the pollen was destroyed via oxydate or other processes. SEM studies reveal the presence of bacteria spherulite structures on dolomite euhedral crystals (2$10 \mu \mathrm{m})$. Minute rhombs, textures and clumps of spherical bodies covering the crystal surfaces indicate that bacteria were involved in the formation of dolomites (Wright, 1999; García del Cura et al., 2001). The fact that these samples have a high TOC content and few pollen grains suggests that the pollen was deeply oxidised by microbial and bacterial reworking during sedimentation and early diagenesis in some dolomicrite facies. Therefore, the hiatuses are probably associated with subaerial exposure and oxidation processes, explaining the low pollen preservation (Burjachs et al., 1996).
Biomarkers: Paq Index and Relative Percentages of $n$-Alkanes

Ficken et al. (2000) proposed a proxy (Paq index) to determine the submerged/floating aquatic macrophyte input (characterised by the predominance of 23 - and 25 -carbon chain lengths) relative to the emergent and terrestrial plant input (dominated by the $\mathrm{C}_{29}$ and $\mathrm{C}_{31}$ homologues) in lake sediments based on the $n$-alkane content of a sample. The profile of the $\mathrm{Paq}$ index values calculated as the $\mathrm{C}_{23}+\mathrm{C}_{25} / \mathrm{C}_{23}+\mathrm{C}_{25}+\mathrm{C}_{29}+\mathrm{C}_{31}$ ratio (Ficken et al., 2000) along the FUENT-1 core appear in Fig. 3. Paq values lower than 0.1 correspond to intervals dominated by terrestrial plants, $0.1-0.4$ to emergent macrophytes and 0.4-1.0 to submerged/floating macrophytes. The increase of this index value can be clearly related to water depth, with lower values indicating shallower conditions versus higher values indicating deeper water conditions.

Schwark et al. (2002) examined the leaf wax $n-C_{27}, n-C_{29}$ and $n-C_{31}$ alkane distribution of present-day plants, showing that, in general, grasses and herbs have high concentrations of the $n-C_{31}$ alkane, while deciduous trees assemblages are dominated by the $n-C_{27}$ alkane. Therefore, despite the fact that vegetation is conditioned by both temperature and moisture, the interpretation of the relative percentages of the $n-C_{27}, n-C_{29}$ and $n$ - $C_{31}$ alkanes can be mainly ascribed to water availability (wet-increasing $\% \quad n-\mathrm{C}_{27}$ versus dry-increasing $\% \quad n-\mathrm{C}_{31}$ episodes). Thus a small Paq index and low $n-C_{27}$ alkane percentage indicate lower water availability and dryer conditions.

\section{Discussion}

The water level in Fuentillejo maar-lake depends primarily on the balance between precipitation and evaporation as it is a closed system. There is no evidence for subsurface water supply, but if it does exist it would be small and associated with the local fractured bedrock. Therefore, the system is very sensitive to changes in the regional hydrological balance and such changes should be reflected by the proxy parameters outlined above. To understand past changes in regional hydrology and climatic conditions, selected proxies from the Fuentillejo sequence were plotted against core depth and age calibration (Fig. 3) and compared with published records from the GISP2 ice core (Grootes and Stuiver, 1997) and the nearby Alboran Sea (Cacho et al., 1999).

During Marine Isotope Stage (MIS) 1 and MIS 2 magnetic minerals and titanium content document an alternation between glacial (cold-arid) and interglacial-like sedimentation characteristics in the FUENT-1 sequence. Close correlation among high Ti content and the high MS values in unit 23 indicates that significant input of detrital particles increased over the last 26 cal. ka BP (Fig. 3). The Ti and MS data coincide with very low TOC, a low Paq index and relatively low $n-\mathrm{C}_{27}$ alkane percentages, suggesting abrupt periods of low lake water level, catchment instability and major erosive processes related to cold and arid phases in central Spain. These cold and arid phases correlate with well-defined cold events in both the GISP2 $\delta^{18} \mathrm{O}$ and the Alboran sea surface temperature (SST) records (Fig. 3). Higher terrigenous input occurred due to reduced vegetation development and soil formation, both conditions which favour erosion in the catchment. This association and the increases in Juniperus pollen may point to the establishment of cold climates and enhanced aridity conditions in central Spain during North Atlantic cold events HE 2 (24.8-23 cal. ka BP), HE 1 (17.5-16 ka cal BP) and the 
Younger Dryas (YD) (12.5-11.5 cal. ka BP). In the Fuentillejo record, during the cold periods the development of forests was limited and an increase in steppe-type herbaceous and bush vegetation was detected. These results reflect a strong influence of North Atlantic cold events during MIS 1 and MIS 2 across central Spain, indicating that the climatic transfer mechanisms from the northern Atlantic to the Iberian Peninsula was almost instantaneous.

These results are in agreement with the evidence of higher intensity of wind systems over the Iberian Peninsula, as reflected by the presence of aeolian deposits (sand and clay dunes) in the Manchega Plain (Bernat and Pérez-González, 2005, 2008) and the Duero Basin (Bateman and Díez Herrero, 1999, 2001; Bernat and Pérez-González, 2005, 2008; GarcíaHidalgo et al., 2007). Clay dunes from the Manchega Plain (close to the Fuentillejo site) were active during five main time windows: (a) 28-25 ka BP; (b) 24-19 ka BP; (c) 12.5-11.5 ka $\mathrm{BP}$; and (d) 9-7 ka BP and their morphologies indicate a predominance of winds coming from the west and north-west (Bernat and Pérez-González, 2008). These authors attributed the aeolian phases to HE2, the Last Glacial Maximum (LGM), the YD and $8.2 \mathrm{ka}$ BP cold events. In the Duero Basin aeolian deposits are all younger than $13.5 \mathrm{ka}$ BP. However, older continental dunes representative of previous arid and windy phases were probably eroded and reworked into aeolian sediments of the subsequent aeolian phases.

Additional evidence for a higher intensity of the northwesterly wind system over the Iberian Peninsula during cold intervals ( $\mathrm{HE}$ and stadials) is revealed by the Alboran marine cores (Cacho et al., 1999; Moreno et al., 2002, 2005; BoutRoumazeilles et al., 2007). Among the main driving mechanisms affecting the Iberian Peninsula are colder and drier northwesterly winds, the effect on climate of colder SST waters entering through the Strait of Gibraltar, or meltwater pulses originating from the Scandinavian Ice Sheet, as previously suggested for lakes in the Pyrenees (González-Samperiz et al. 2006) and other Mediterranean records (Magri and Parra, 2002; Sangiorgi et al., 2002; Tzedakis et al., 2003, 2004; Bahr et al., 2005). Nevertheless, Moreno et al. (2002, 2005, 2007a) indicate that Saharan dust transport was stronger during the $\mathrm{D} / \mathrm{O}$ stadial periods than during HE. This early response of the Saharan winds highlights the potential importance of lowlatitude climatic processes in the global array of abrupt climate change (Moreno et al., 2005).

In glacial lakes from the Pyrenees, HE 3, HE 2 and HE 1 were characterised by increases in pollen percentages for steppe taxa and decreases in Juniperus that point to the establishment of cold and dry conditions (González-Samperiz et al., 2006). This is contrary to the Juniperus and steppe signals from the FUENT-1 sequence and may indicate important differences in temperature and moisture availability related to strong differences in altitude-latitude and geomorphological setting between these lacustrine records. The Fuentillejo maar-lake, compared to lakes from the Pyrenees (e.g. González-Samperiz et al., 2006 and references herein), the Cantabrian mountains (Jiménez Sánchez and Farias, 2002) and the northwestern Iberian Range (Peñalba et al., 1997; Ruiz-Zapata et al., 2002 and references herein), had a stronger Mediterranean climatic influence during the last $50 \mathrm{ka}$ as it is at lower altitude and lies to the south. Rapid changes from cold to temperate climatic conditions synchronous with $\mathrm{D} / \mathrm{O}$ events have been recorded in lake deposits from the south of France (Thouveny et al., 1994). Similarly, a connection between $D / O$ events and oscillations in the evaporation/precipitation rate of some Italian lakes has been observed (Allen et al., 1999; Ramrath et al., 1999). These linkages point to a coupling between $D / O$ events and lake hydrology in the Mediterranean region and also point to a rapid atmospheric relationship between Greenland and the Mediterranean basin.

The Fuentillejo sequence also records the development of Holocene cold and arid episodes in central Spain, particularly from 8-7.1 cal. ka BP (lower part of subunit 23.7) that is marked by a decrease in forest, an increase in Juniperus and biomarkers-sedimentary facies that indicate a shallower lake level. Therefore, in the FUENT-1 sequence there is a late impact of the 8.2 ka event which is seen in the North Atlantic records (e.g. Wiersma and Renssen, 2006, and references therein). Nevertheless, the age-depth model of the FUENT-1 core might be adjusted in the future with additional dates. Short cold and arid phases during the Holocene were identified but were less pronounced from 9.2-8.6, 7.5-7 and 5.5-5 cal. ka BP. During the interstadials of the last $50 \mathrm{ka}$, the development of forest was limited due to the semi-arid character of this region. This scarce forest development can be interpreted from the Holocene pollen record of mesic and thermophilous vegetation of the FUENT-1 sequence (Fig. 3), in which only $40-50 \%$ of total pollen come from arboreal associations. These values for arboreal pollen content are low compared with other northern and higher-altitude Spanish pollen sequences (e.g. Ruiz-Zapata et al., 2002; González-Samperiz et al., 2006). Nevertheless, there is abundant evidence of strong anthropogenic influence on the Manchega Plain during the Holocene, especially since the Bronze and Iron Ages with Mediterranean-type intensive farming (Martín et al., 1993; Nájera and Molina, 2004; Molina et al., 2005)

In contrast, the FUENT-1 sequence documents a predominance of carbonate sedimentation during MIS 3 and during interstadials of MIS 2. The high increases in Chenopodiacea, Artemisia and Ephedra observed in the FUENT-1 core are interpreted as arid and warm phases since those plants are associated with dry climates. Traditionally they have been also linked to cold climates in studies from northern Europe (de Beaulieu and Reille, 1984, 1992; Reille and de Beaulieu, 1990) and other Mediterranean sites (Allen et al., 1999; Warny et al., 2003; Tzedakis et al., 2004), but they are found at present in different parts of central and south Spain and thus can be interpreted to represent warmer conditions in the Fuentillejo record, which is also reflected by more saline conditions of the carbonate facies association. Plants were conditioned by a long, warm, dry season. This evidence is further supported by a low Paq index, indicative of a low lake level, and a relatively low TOC content resulting from oxidation processes during subaerial exposure.

Dolomitic facies that occurred especially during the interstadials of MIS 3 of the FUENT-1 sequence are interpreted as being formed during warm phases linked to marked and prolonged arid conditions, but with short episodes of increasing rainfall. In fact, the formation of dolomite in this closed lacustrine environment would have required episodic flooding by fresh water (Folk and Land, 1975; Trichet et al., 2001), allowing saline brines to be periodically mixed with fresh water in a low lake system. The salinity drops drastically, but the $\mathrm{Mg} /$ Ca ratio remains almost as high as it was initially. The top of subunit 20.2 is interpreted as the driest and warmer period from sedimentological (dolomite-zeolite, very low lake level) and geochemical proxies $(<0.5 \%$ TOC, $<0.3 \mathrm{Paq}$ index). This phase is chronologically coincident with HE 5 (Fig. 3). Other evidence of dry and warmer phases is described in the sedimentary record, where ephemeral dolomicritic lacustrine facies are developed in subunits 20.2, 22.2, 22.2-22.3 boundary, 23.2 and 23.4 (Fig. 3). These data also support an interpretation of aridity and higher temperatures in the Fuentillejo area causing the retreat of arboreal vegetation cover, a predominance of steppe taxa and a markedly low 
Table 3 Sedimentological geochemical and main plant taxa that characterised the YD and HE events identified in the Fuentillejo lacustrine record over the last $50 \mathrm{cal}$. ka BP

\begin{tabular}{|c|c|c|c|c|}
\hline $\begin{array}{l}\text { Climatic } \\
\text { events }\end{array}$ & $\begin{array}{l}\text { FUENT-1 } \\
\text { (cal. ka BP) }\end{array}$ & Sedimentary units - depth & FUENT-1 lacustrine evidence & Interpretation \\
\hline YD & $12.5-11.5$ & Lower part $23.54 .5-5.25 \mathrm{~m}$ & $\begin{array}{l}\text { Detrital input, erosion, low lake level, } \\
\text { low organic productivity, pollen hiatus }\end{array}$ & Cold and arid \\
\hline HE 1 & $17.6-16.2$ & Subunit $23.36 .5-7 \mathrm{~m}$ & $\begin{array}{l}\text { Detrital input, erosion, low lake level, } \\
\text { low organic productivity, high Juniperus content }\end{array}$ & Cold and arid \\
\hline HE 2 & $24.8-23$ & Subunit $23.19-10 \mathrm{~m}$ & $\begin{array}{l}\text { Detrital input, erosion, low lake level, } \\
\text { low organic productivity, highest Juniperus content }\end{array}$ & Cold and arid \\
\hline HE 3 & $31-29.3$ & Middle $22.211 .6-12.5 \mathrm{~m}$ & $\begin{array}{l}\text { Carbonatic (dolomite) sedimentation, } \\
\text { low lake level, high detrital organic content, } \\
\text { pollen hiatus }\end{array}$ & Warm and arid \\
\hline HE 4 & $39.4-38.2$ & Middle $21.215 .45-15.75 \mathrm{~m}$ & $\begin{array}{l}\text { Carbonatic (dolomite) sedimentation, } \\
\text { low lake level, organic matter degradation, } \\
\text { high Juniperus and steppe taxa content }\end{array}$ & Less cold and arid \\
\hline HE 5 & $46.1-45$ & Top $20.217 .9-18.3 \mathrm{~m}$ & $\begin{array}{l}\text { Sapropelic-carbonatic sedimentation, } \\
\text { analcime, dissolution of Fe oxides, } \\
\text { organic matter degradation, high salinity, } \\
\text { low lake level, desiccation cracks, } \\
\text { highest steppe taxa content }\end{array}$ & Warm and arid \\
\hline
\end{tabular}

hydrological budget that depends on the seasonal rainfall. This warmer MIS 3 in the FUENT-1 core is similar to the Area Longa (north-west Spain) record (Gómez-Orellana et al., 2007) where stadial phases were less cold than MIS 2 stadials.

The FUENT-1 sequence shows different environmental responses to $\mathrm{HE}$ (Fig. 3 and Table 3). HE 2, HE 1 and the YD have similar cold and arid patterns. During HE 3 the Fuentillejo record is characterised by a relatively high TOC content, very low detrital input, low lake level conditions (reflected by a low Paq index, desiccation cracks and dolomicritic facies) and a pollen hiatus. Nevertheless, carbonate facies, reduced detrital input (very low MS and Ti content), low lake level conditions, a decrease in $\mathrm{TOC}$, an increase in Juniperus and the presence of steppic plants characterise the FUENT-1 HE4 event. Dolomite-zeolite facies, very low lake level conditions and TOC found at the top of subunit 20.2 are chronologically coincident with HE5.

HE 4, HE 2, HE 1 and the YD in the FUENT-1 core are immediately followed by increases of warm steppe pollen assemblages that document rapid warming similar to the $\mathrm{D} / \mathrm{O}$ cycles but do not imply increasing humidity in the area. The proxies in FUENT-1 indicate that the start of interstadials in central Spain during MIS 2 and 3 was marked by an increase in temperature and reduced moisture availability. In the Alboran and west lberia sea sediments, the increase of steppic plants is coeval with HE events that have been associated with low precipitation and colder temperatures over Spain over the last $50 \mathrm{ka}$ BP (Sánchez-Goñi et al., 2000, 2002; CombourieuNebout et al., 2002; Roucoux et al., 2005). However, the Alboran and west lberia deep-ocean steppe pollen records are different compared with the pollen record at the FUENT-1 core. This different continental pollen signal was observed in northwestern Spain (Gómez-Orellana et al., 2007), suggesting that all offshore pollen records suffer from both the probable underrepresentation of less mobile palynomorphs and the pooling of pollen from different source biomes. Moreover, this can be explained by an erroneous interpretation of steppe taxa found in deep-sea records because, as discussed above, these plants in Spain can occur in desert/semi-arid environments under warmer temperature. This indicates that although Mediterranean millennial variability was governed by the North Atlantic $\mathrm{D} / \mathrm{O}$ cycles, the intensity and, in some cases, the persistence of these climatic oscillations were further modified by regional processes.
This evidence supports arid conditions in the Fuentillejo area but warmer temperatures in comparison to the west Iberia and Mediterranean marine records, and points out different HE 4HE 2-HE 1-YD and HE 5-HE 3 signals in central Spain. The HE 3 cold event has an attenuated signal at the Iberian Peninsula latitudes. In fact, HE 3 has not been identified in some North Atlantic Ocean areas (Cortijo et al., 1995; Chapman and Shackleton, 1998) or along the Iberian margin (Zahn et al., 1997) but it is well represented in the Alboran record by a relatively slow cooling and a final sharp warming (Cacho et al., 1999). Three long pollen records from Greece suggest that the response of vegetation to the difference in the intensity of the $\mathrm{HE}$ events varied considerably and were associated with moisture availability (Tzedakis et al., 2004). The most noticeable contraction of temperate tree populations in Greece was associated with HE 4. In the North Atlantic, HE 4 is thought to have been one of the most extreme events of MIS 3 in terms of the flux of Laurentide-derived ice-rafted detritus (McManus et al., 1998). Along the Portuguese margin, the HE 4 record is characterised by greater decreases in SSTs and ocean ventilation compared to HE 3 (Bard et al., 2000). Otherwise, the Alboran alkenone-derived SST record shows equal reductions during HE 3 and HE 4 (Cacho et al., 1999).

\section{Conclusions}

This study identifies climate variations in central Spain at millennial scales in response to variations in precipitation regimes that imprint arid signals during Dansgaard/Oeschger (D/O) stadials and HE events. The multi-proxy data from the Fuentillejo sequence reveals the complexity of the environmental changes, in particular the hydrological variations in this lake system. TOC, Ti, MS, steppe taxa, Juniperus content, sedimentary facies and Paq index values show rapid oscillations attributed to strong variations in lake water level. These are inferred to reflect fluctuations in rainfall that occurred in the Fuentillejo area, which correspond to D/O cycles. Cold-arid phases were defined by high MS, low lake level conditions (low Paq index), high Juniperus content, low TOC and high detrital input. During MIS 1 and MIS 2, cold climates and enhanced aridity conditions in the Fuentillejo lacustrine sequence are 
correlated with North Atlantic cold events HE 2 (24.8-23 cal. ka BP), HE 1 (17.5-16 cal. ka BP) and the YD (12.5-11.5 cal. ka $\mathrm{BP})$. These phases were influenced by more vigorous northwesterly winds over the Iberian Peninsula combined with the southern displacement of the ITCZ belt. Another cold and arid episode is recorded from $8-7.1 \mathrm{cal}$. ka BP that can be considered as a late impact of the $8.2 \mathrm{ka}$ event, which is also observed in other North Atlantic records, although a certain mismatch on the radiocarbon chronology cannot be totally discarded. Short cold and arid phases during the Holocene were identified at $9.2-8.6,7.5-7$ and $5.5-5$ cal. ka BP. Many of the FUENT-1 features correlate well with the Greenland ice core records, demonstrating that the closely coupled oceanatmosphere system of the Northern Hemisphere during the last glacial extended its influence at least as far as the west continental Mediterranean region.

Warm-arid phases are characterised by dolomite-mud facies, an increase in Chenopodiaceae, Artemisia and Ephedra steppe taxa, relatively low TOC content, a low Paq index and an increase in the relative percentage of the $n$ - $\mathrm{C}_{31}$ alkane. These warm and arid episodes produced lower lake levels and more saline-alkaline conditions that occurred more frequently during MIS 3 and interstadials of MIS 2 in the FUENT-1 core. $\mathrm{HE} 4, \mathrm{HE} \mathrm{2,} \mathrm{HE} 1$ and YD were immediately followed by increases of warm steppe pollen assemblages in the FUENT-1 core that document rapid warming similar to the D/O cycles but do not imply increasing humidity in the area.

Acknowledgements This paper was made possible by funding from the Spanish Inter-Ministry Commission of Science and Technology (CICYT), project CGL2004-06212/BTE, 'Variabilidad climática y ambiental en el centro de la Península Ibérica durante el Cuaternario: Estudio de alta resolución del registro lacustre del sondeo FUENT-1 (laguna de Fuentillejo, Ciudad Real)' and the IGME through the project CC 54.020, 'Estudio Paleoclimático del Maar de Fuentillejo (Ciudad Real)'. X-ray diffraction and geochemical data were obtained by the IGME laboratory staff (laboratory director J. A. Martín-Rubí). We thank Mark Besonen (University of Massachusetts) for his suggestions and language revision, which improved an earlier version of the manuscript. We also thank reviewers, $M$. Talbot and $S$. Warny for the helpful comments and suggestions for manuscript improvement.

\section{References}

Allen JRM, Brandt $U$, Brauer A, Hubberten HW, Huntley B, Keller J, Kraml M, Mackensen A, Mingram J, Negendank JFW, Nowaczyk NR, Oberhänsli H, Watts WA, Wulf S, Zolitschka B. 1999. Rapid environmental changes in southern Europe during the last glacial period. Nature 400: 740-743.

Ancochea E. 1983. Evolución espacial y temporal del volcanismo reciente de España Central. PhD thesis, Universidad Complutense, Madrid.

Bahr A, Lamy F, Arz HW, Kuhlmann H, Weber G. 2005. Late glacial to Holocene climate and sedimentation history in the NW Black Sea. Marine Geology 214: 309-322.

Bard E, Rostek F, Turon JL, Gendreau S. 2000. Hydrological Impact of Heinrich events in the Subtropical Northeast Atlantic. Science 289: 1321-1324.

Bateman MD, Díez Herrero A. 1999. Thermoluminescence dates and palaeoenvironmental information of the late Quaternary sand deposits, Tierra de Pinares, Central Spain. Catena 34: 277-291.

Bateman MD, Díez Herrero AD. 2001. The timing and relation of aeolian sand deposition in Central Spain to the aeolian sand record of NW Europe. Quaternary Science Reviews 20: 779-782.

Baudin F, Combourieu-Nebout N, Zahn R. 2007. Signatures of rapid climatic changes in organic matter records in the western Mediter- ranean Sea during the last glacial period. Bulletin de la Société Géologique de France 1: 3-10.

Bernat M, Pérez-González A. 2005. Campos de dunas y mantos eólicos de Tierra de Pinares (Sureste de la cuenca del Duero, España). Boletín Geológico y Minero 116: 23-38.

Bernat M, Pérez-González A. 2008. Inland aeolian deposits of the Iberian Peninsula: sand dunes and clay dunes of the Duero Basin and the Manchega Plain. Geomorphology 102: 207-220.

Birks HJB, Birks HH. 1980. Quaternary Palaeoecology. Edward Arnold: London.

Boessenkool KP, Brinkhuis H, Schönfeld J, Targarona J. 2001. North Atlantic sea-surface temperature changes and the climate of western lberia during the last deglaciation: a marine palynological approach. Global and Planetary Change 30: 33-39.

Bonadonna FP, Villa JM. 1984. Estudio geocronológico del vulcanismo de las Higueruelas. I. Reunión Estratigrafía Regional Castilla-La Mancha (Albacete). Espacio y Sociedad III: 249-253.

Bout-Roumazeilles V, Combourieu Nebout N, Peyron O, Cortijo E, Landais A, Masson-Delmotte V. 2007. Connection between South Mediterranean climate and North African atmospheric circulation during the last 50,000 yr BP North Atlantic cold events. Quaternary Science Reviews 26: 3197-3215.

Burjachs F, Juliá R. 1994. Abrupt climatic changes during the Last Glaciation based on pollen analysis of the Abric Romani, Catalonia, Spain. Quaternary Research 42: 308-315.

Burjachs F, Rodó X, Comín FA. 1996. Gallocanta: ejemplo de secuencia palinológica en una laguna efímera. In Estudios Palinológicos, XI Simposio de Palinología Ruiz-Zapata B (ed.). Universidad de Alcalá, Spain; pp. 25-29.

Cacho I, Grimalt JO, Pelejero C, Canals M, Sierro FJ, Flores JA, Shackleton N. 1999. Dansgaard-Oeschger and Heinrich event imprints in Alboran Sea paleotemperatures. Paleoceanography 14: 698-705.

Cacho I, Grimalt JO, Sierro FJ, Shackleton N, Canals M. 2000. Evidence of enhanced Mediterranean thermohaline circulation during rapid climatic coolings. Earth and Planetary Science Letters 183: 417-429.

Cacho I, Shackleton N, Elderfield H, Sierro FJ, Grimalt JO. 2006. Glacial rapid variability in deep-water temperature and $\delta^{18} \mathrm{O}$ from the Western Mediterranean Sea. Quaternary Science Reviews 25: 3294-3311.

Carrión JS, Munuera M, Navarro C. 1998. The palaeoenvironment of Carihuela Cave (Granada, Spain): a reconstruction on the basis of palynological investigations of cave sediments. Review of Palaeobotany and Palynology 99: 317-340.

Castanier S, Bernet-Rollande MC, Maurin A, Perthuisot JP. 1993. Effects of microbial activity on the hydrochemistry and sedimentology of Lake Logipi, Kenya. Hidrobiologia 267: 99-112.

Channell JET. 2006. Late Brunhes polarity excursions (Mono Lake, Laschamp, Iceland Basin and Pringle Falls) recorded at ODP site 919 (Irminger Basin). Earth and Planetary Science Letters 244: 378-393.

Chapman MR, Shackleton NJ. 1998. Millennial-scale fluctuations in North Atlantic heat flux during the last 150,000 years. Earth and Planetary Science Letters 159: 57-70.

Combourieu-Nebout N, Turon JL, Zahn R, Capotondi L, Londeix L, Pahnke K. 2002. Enhanced aridity and atmospheric high pressure stability over the western Mediterranean during North Atlantic cold events of the past 50,000 years. Geology 30: 863-866.

Cortijo E, Yiou P, Labeyrie L, Cremer M. 1995. Sedimentary record of rapid climatic variability in the North Atlantic ocean during the last glacial cycle. Paleoceanography 10: 911-926.

Coûteax M. 1977. A propos de l'interpretation des analyses polliniques de sediments minéraux, principalement archéologiques. In Le Milieu Végétal, les faunas et I'Homme. Supplément Bulletin AFEQ 47: 259 276

de Beaulieu JL, Reille M. 1984. A long upper-Pleistocene pollen record from Les Echets near Lyon, France. Boreas 13: 111-132.

de Beaulieu JL, Reille M. 1992. The last climatic cycle at La Grande Pile (Vosges, France): a new pollen profile. Quaternary Science Reviews 11: $431-438$.

Fernández García F. 1986. El clima de la Meseta Meridional: los tipos de tiempo. Universidad Autónoma de Madrid, Madrid.

Ficken KJ, Li B, Swain DL, Eglinton G. 2000. An n-alkane proxy for the sedimentary input of submerged/floating freshwater aquatic macrophytes. Organic Geochemistry 31: 745-749. 
Florschütz F, Menéndez Amor J, Wijmstra TA. 1971. Palynology of a thick Quaternary succession in southern Spain. Palaeogeography, Palaeoclimatology, Palaeoecology 10: 233-264.

Folk RL, Land LS. 1975. Mg/Ca ratio and salinity: two controls over crystallization of dolomite. American Association of Petroleum Geologists Bulletin 59: 60-68.

Font-Tullot I. 1983. Pisos bioclimáticos de España. Lazaroa 5: 33-43. Font-Tullot I. 1988. Historia del clima en España. Cambios climáticos y sus causas. Instituto Nacional de Meteorología, Madrid.

Galán L, Vegas J, García-Cortés A. 2007. Caracterización de las propiedades físicas en registros lacustres mediante GEOTEK Multisensor Core Logger. Aplicación para el estudio paleoclimático del maar de Fuentillejo. In Contribuciones al estudio del periodo Cuaternario Lario J, Silva PG (eds). Sección de Publicaciones de la Escuela Técnica Superior de Ingenieros Industriales, Universidad Politécnica de Madrid; 187-188.

Gallardo-Millán JL. 2004. Evolución geodinámica de las cuencas neógenas del Campo de Calatrava (Ciudad Real) y su relación con el volcanismo reciente. PhD thesis, Universidad Complutense de Madrid.

Gallardo-Millán JL, Pérez-González A. 2000. Magnetoestratigrafía del relleno neógeno en las cuencas del Campo de Calatrava (Ciudad Real). Geo-Temas 1: 101-104.

Gallardo-Millán JL, Ancochea E, Pérez-González A. 2002. Secuencia magnetoestratigráfica y edad de los materiales volcánicos y sedimentarios de Poblete (Ciudad Real). Geogaceta 32: 35-38.

Gallardo-Millán JL, Vegas J, García-Cortés A, Galán L, Pérez-González A, Martín-Serrano A. 2008. Primeros resultados del estudio magnetoestratigráfico del registro lacustre del maar de Fuentillejo (Región volcánica del Campo de Calatrava, Ciudad Real): implicaciones cronológicas. Geo-Temas 10: 245-248.

García del Cura MA, Calvo JP, Ordoñez S, Jones BF, Cañaveras JC. 2001. Petrographic and geochemical evidence for the formation of primary, bacterially induced lacustrine dolomite: La Roda 'white earth' (Pliocene, central Spain). Sedimentology 48: 897-915.

García-Hidalgo JF, Temiño J, Segura M. 2007. Holocene aeolian development in Central Spain: chronology, regional correlations and causal processes. Quaternary Science Reviews 26: 2661-2673.

Goeury CL, Beaulieu JL. 1979. Á propos de la concentration du pollen à I'aide de la liquer de Thoulet dans les sediments minéraux. Pollen et Spores 21: 239-251.

Gómez-Orellana L, Ramil-Rego P, Muñoz-Sobrino C. 2007. Th Würm in NW Iberia, a pollen record from Area Longa (Galicia). Quaternary Research 67: 438-452.

González-Samperiz P, Valero-Garcés BL, Moreno A, Jalut G, GarcíaRuiz JM, Martí-Bono C, Delgado-Huertas A, Navas A, Otto T, Dedoubat JJ. 2006. Climate variability in the Spanish Pyrenees during the last 30,000 yr revealed by the El Portalet sequence. Quaternary Research 66: 38-52.

Grimm EC. 1987. CONISS: a FORTRAN 77 program for stratigraphically constrained cluster analysis by the method of incremental sum of squares. Computers and Geosciences 13: 13-35.

Grootes P, Stuiver M. 1997. Oxygen 18/16 variability in Greenland snow and ice with 103- to 105-year time resolution. Journal of Geophysical Research 102: 26455-26470.

Hirokuni O. 2005. Recurrent geomagnetic excursions: a review for the Brunhes normal polarity chron. Journal of Geography 114: 174-193.

Holt JW, Kirschvink JL. 1996. Geomagnetic field inclination for the past $400 \mathrm{kyr}$ from the $1-\mathrm{km}$ core of the Hawaii Science Drilling Project. Journal of Geophysical Research 101: 11655-11663.

Jiménez Sánchez M, Farias P. 2002. New radiometric and geomorphologic evidence of Last Glacial Maximum older than $18 \mathrm{ka}$ in SW European mountains: the example of Redes Natural Park (Cantabrian mountains, NW Spain). Geodinamica Acta 15: 93-101.

Johnsen CJ, Dansgaard W, Clausen HB, Langway CC. 1972. Oxygen isotope profiles through the Antarctic and Greenland Ice Sheets. Nature 235: 429-434.

Johnsen S, Clausen HB, Dansgaard W, Fuhrer K, Gundestrup N, Hammer CU, Iversen P, Jouzel J, Stauffer B, Steffensen JP. 1992. Irregular interstadials recorded in a new Greenland ice core. Nature 359: $311-313$.

Last WM, De Dekker P. 1990. Modern and Holocene carbonate sedimentology of two saline volcanic maar lakes, southern Australia. Sedimentology 37: 967-981.
Lucini M, Torres T, Llamas JF, Canoira L, Ortiz JE, García de la Morena MA. 2000. Geoquímica orgánica de las lutitas lacustres de las cuencas cenozoicas del Duero y Ebro. Geogaceta 28: 93-96.

Magri D, Parra I. 2002. Late Quaternary western Mediterranean pollen records and African winds. Earth and Planetary Science Letters 200: 401-408.

Martín C, Fernández M, Fernández MD, Gilman A. 1993. The Bronze Age of La Mancha. Antiquity 67: 23-45.

McManus JF, Anderson RF, Broecker WS, Fleischer MQ, Higgins SM. 1998. Radiometrically determined fluxes in the sub-polar North Atlantic during the last 140,000 years. Earth and Planetary Science Letters: 135: 29-43.

Minyuk PS, Brigham-Grette J, Melles M, Borkhodoev BY, Glushkova O. 2007. Inorganic geochemistry of El'gygytgyn Lake sediments (northeastern Russia) as an indicator of paleoclimatic change for the last $250 \mathrm{kyr}$. Journal of Paleolimnology 37: 123-133.

Molina F, Nájera T, Aranda G, Sánchez M, Haro M. 2005. Recent fieldwork at the Bronze Age fortified site of Motilla de Azuer (Daimiel, Spain). Antiquity 79: Project Gallery. http://antiquity. ac.uk/projgall/aranda/index.html [2 March 2009].

Montserrat J. 1992. Evolución glaciar y postglaciar del clima y la vegetación en la vertiente sur del Pirineo: Estudio palinológico. Instituto Pirenaico de Ecología, Zaragoza.

Moore PD, Webb JA, Collinson ME. 1991. Pollen Analysis. Blackwell Scientific Publications: Oxford.

Moreno A, Cacho I, Canals M, Prins MA, Sánchez-Goñi MF, Grimalt JO, Weltje G). 2002. Saharan dust transport and high-latitude glacial climatic variability: the Alboran sea record. Quaternary Research $\mathbf{5 8}$ : 318-328.

Moreno A, Cacho I, Canals M, Grimalt JO, Sánchez-Goñi MF, Shackleton N, Sierro FJ. 2005. Links between marine and atmospheric processes oscillating on a millennial time-scale: a multi-proxy study of the last 50,000yr from the Alboran Sea (Western Mediterranean Sea). Quaternary Science Reviews 24: 1623-1636.

Moreno A, Cacho I, Canals M, Grimalt JO, Sanchez-Goñi MF, Sierro FJ. 2007a. Conexiones climáticas de escala milenaria entre procesos oceánicos y atmosféricos durante el último ciclo glaciar: estudio multidisciplinar de un sondeo del mar de Alborán (Mediterráneo occidental). Revista de la Sociedad Geológica de España 20: 31-52

Moreno A, Giralt S, Valero-Garcés B, Sáez A, Bao R, Prego R, Pueyo JJ, González-Samperiz P, Taberner C. 2007b. A $14 \mathrm{kyr}$ record of the tropical Andes: the Lago Chungará sequence $\left(18^{\circ} \mathrm{S}\right.$, northern Chilean Altiplano). Quaternary International 161: 4-21.

Nájera T, Molina F. 2004. La edad del Bronce en la Mancha: problemática y perspectivas de la investigación. In La edad del Bronce en tierras levantinas $y$ zonas limitrofes, Hernández L, Hernández $M$ (eds). Ayuntamiento de Villena: Alicante; 531-540.

Nowackzyk NR, Minyuk PS, Melles M, Brigham-Grette J, Glushkova O, Nolan N, Lozhkin AV, Stetsenko TV, Andersen PM, Forman SL. 2002. Magnetostratigraphic results from impact crater Lake El'gygytgyn, northeastern Siberia: a $300 \mathrm{kyr}$ long high-resolution terrestrial palaeoclimatic record from the Arctic. Geophysical Journal International 150: 109-126.

Ordóñez S, Sanchez-Moral S, García del Cura MA, Rodriguez-Badiola E. 1994. Precipitation of salts from $\mathrm{Mg}^{2+}{ }_{-}\left(\mathrm{Na}^{+}\right)-\mathrm{SO}_{4}^{2-}{ }_{-} \mathrm{Cl}^{-}$playa-lake brines: the endorheic saline ponds of La Mancha, central Spain. In Sedimentology and Geochemistry of Modern and Ancient Saline Lakes, SEPM Special Publication No. 50. Society of Economic Paleontologists and Mineralogists: Tulsa, OK; 61-71.

Ortiz JE, Torres T, Delgado A, Julià R, Lucini M, Llamas FJ, Reyes E, Soler V, Valle M. 2004. The palaeoenvironmental and palaeohydrological evolution of Padul Peat Bog (Granada, Spain) over one million years, from elemental, isotopic, and molecular organic geochemical proxies. Organic Geochemistry 35: 1243-1260.

Ortiz JE, Torres T, Delgado A, Reyes E, Llamas JF, Soler V, Raya J. 2006. Pleistocene paleoenvironmental evolution at continental middle latitudes inferred from carbon and oxygen stable isotope analysis of ostracodes from the Guadix-Baza Basin (Granada, SE Spain). Palaeogeography, Palaeoclimatology, Palaeoecology 240: 535 561.

Peñalba MC, Arnold M, Guiot J, Duplessy JC, De Beaulieu JL. 1997. Termination of the Last Glaciation in the Iberian Peninsula inferred 
from the pollen sequence of Quintanar de la Sierra. Quaternary Research 48: 205-214.

Pons A, Reille M. 1988. The Holocene and Upper Pleistocene pollen record from Padul (Granada, Spain): a new study. Palaeogeography, Palaeoclimatology, Palaeoecology 66: 243-263.

Portero JM, Ramírez JI, Ancochea E, Pérez-González A. 1988. Geological Map of Spain 1:50.000 (MAGNA) Hoja No. 784 IGME: Ciudad Real.

Ramrath A, Nowaczyk NR, Negendank JFW. 1999. Sedimentological evidence for environmental changes since 34,000 years BP from Lago di Mezzano, central Italy. Journal of Paleolimnology 21: 423 435

Reille M, de Beaulieu JL. 1990. History of the Würm and Holocene vegetation in Western Velay (Massif Central, France): a comparison of pollen analysis from three corings at Lac du Bouchet. Review of Paleobotany and Palynology 54: 233-248.

Reimer PJ, Baillie MGL, Bard E, Bayliss A, Beck JW, Bertrand CJH, Blackwell PG, Buck CE, Burr GS, Cutler KB, Damon PE, Edwards RL, Fairbanks RG, Friedrich $M$, Guilderson TP, Hogg AG, Hughen KA, Kromer B, McCormac G, Manning S, Ramsey CB, Reimer RW, Remmele S, Southon JR, Stuiver M, Talamo S, Taylor FW, van der Plicht J, Weyhenmeyer C. 2004. INTCAL04 terrestrial radiocarbon age calibration, 0-26 cal kyr BP. Radiocarbon 46: 1029-1058.

Roucoux KH, de Abreu L, Shackleton NI, Tzedakis PC. 2005. The response of NW Iberian vegetation to North Atlantic climate oscillations during the last 65 kyr. Quaternary Science Reviews 24: 1637 1653.

Ruiz-Zapata MB, Gil García MJ, Dorado M, Valdeolmillos A, Vegas J, Pérez-González A. 2002. Clima y vegetación durante el Tardiglaciar y el Holoceno en la Sierra de Neila (Sistema Ibérico Noroccidental). Cuaternario y Geomorfología 16: 9-20.

Sánchez-Goñi MF, Eynaud F, Turon JL, Shackleton NJ. 1999. Highresolution palynological record off the Iberian margin: direct landsea correlation for the Last Interglacial complex. Earth and Planetary Science Letters 171: 123-137.

Sánchez-Goñi MF, Turon JL, Eynaud F, Gendreau S. 2000. European climatic response to millennial-scale changes in the atmosphereocean system during the Last Glacial Period. Quaternary Research 54: 394-403.

Sánchez-Goñi MF, Cacho I, Turon JL, Guiot J, Sierro FJ, Peypouquet JP, Grimalt JO, Shackleton NJ. 2002. Synchroneity between marine and terrestrial responses to millennial scale climatic variability during the last glacial period in the Mediterranean region. Climate Dynamics 19: 95-105.

Sangiorgi F, Capotondi L, Brinkhuis H. 2002. A centennial scale organic-walled dinoflagellate cyst record of the last deglaciation in the South Adriatic Sea (Central Mediterranean). Palaeogeography, Palaeoclimatology, Palaeoecology 186: 199-216.

Schulte L, Julià R, Burjachs F, Hilgers A. 2009. Middle Pleistocene to Holocene geochronology of the River Aguas terrace sequence (Iberian Peninsula): fluvial response to Mediterranean environmental change. Geomorphology (in press).

Schwark L, Zink K, Lechterbeck J. 2002. Reconstruction of postglacial to early Holocene vegetation history in terrestrial Central Europe via cuticular lipid biomarkers and pollen records from lake sediments. Geology 30: 463-466.

Singer A, Stoffers P. 1980. Clay mineral diagenesis in two East African lake sediments. Clay Minerals 15: 291-307.

Stoffers P, Holdship S. 1975. Diagenesis of sediments in an alkaline lake: Lake Manyara, Tanzania. In Proceedings of the 9th International Conference on Sedimentology Nice; 7, 211.
Thouveny N, De Beaulieu JL, Bonifay E, Creer KN, Guiot J, Icole M, Johnsen S, Jouzel I, Reille M, Williams T, Williamson D. 1994. Climate variations in Europe over the past $140 \mathrm{kyr}$ deduced from rock magnetism. Nature 371: 503-506.

Trichet J, Défarge C, Tribble J, Sansone F. 2001. Christmas Island lagoonal lakes, models for the deposition of carbonate-evaporiteorganic laminated sediments. Sedimentary Geology 140: 177189.

Tzedakis PC, Andrieu V, de Beaulieu JL, Crowhurts S, Follieri NJ, Hooghiemstra H, Magri D, Reille M, Sadori L, Shackleton NJ, Wijmstra TA. 1997. Comparison of terrestrial and marine records of changing climate of the last 500,000 years. Earth and Planetary Science Letters 150: 171-176.

Tzedakis PC, McManus PC, Hooghiemstra H, Oppo DW, Wijmstra TA. 2003. Comparison of changes in vegetation in northeast Greece with records of climate variability on orbital and suborbital frequencies over the last 450,000 years. Earth and Planetary Science Letters 212 : 197-212.

Tzedakis PC, Frogley MR, Lawson IT, Preece RC, Cacho I, de Abreu L. 2004. Ecological thresholds and patterns of millennial-scale climate variability: the response of vegetation in Greece during the last glacial period. Geology 32: 109-112.

Tzedakis PC, Hooghiemstra H, Pälike H. 2006. The last 1.35 million years at Tenaghi Philippon: revised chronostratigraphy and long-term vegetation trends. Quaternary Science Reviews 25: 3416-3430.

Valero-Garcés BL, González-Sampériz P, Navas A, Machín J, DelgadoHuertas A, Peña-Monné IL, Sancho-Marcén C, Stevenson T, Davis B. 2004. Paleohydrological fluctuations and steppe vegetation during the last glacial maximum in the central Ebro valley (NE Spain). Quaternary International 122: 43-55.

Vegas J, Galán L, Pérez-González A, García-Cortés A. 2004. El archivo lacustre del maar de Fuentillejo (Campo de Calatrava): primeros protocolos científicos y estrategia de trabajo para el estudio paleoclimático del Cuaternario en el centro de España. Boletín Geológico y Minero 115: 641-650.

Vegas J, García-Cortés A, Galán L, Pérez-González A, Martín-Serrano A. 2006. El registro sedimentario lacustre del maar de Fuentillejo (Ciudad Real). Boletín Geológico y Minero 117: 339-349.

Von der Borch CC, Lock D. 1979. Geological significance of Coorong dolomites. Sedimentology 26: 813-824.

Warny SA, Bart PJ, Suc JP. 2003. Timing and progression of climatic tectonic and glacioeustatic influences on the Messinian Salinity Crisis. Palaeogeography, Palaeoclimatology, Palaeoecology 202 59-66.

Wiersma AP, Renssen H. 2006. Model-data comparison for the $8.2 \mathrm{ka}$ BP event: confirmation of a forcing mechanism by catastrophic drainage of Laurentide Lakes. Quaternary Science Reviews 25 $63-88$.

Williamson D, Jelinowska A, Kissel C, Tucholka P, Gibert E, Gasse F, Massault M, Taieb M, Van Campo E, Wieckowski K. 1998. Mineralmagnetic proxies of erosion/oxidation cycles in tropical-maar-lake sediments Lake Tritrivakely, Madagascar: paleoenvironmental implications. Earth and Planetary Science Letters 155: 205-219.

Wright DT. 1999. The role of sulphate-reducing bacteria and cyanobacteria in dolomite formation in distal ephemeral lakes of the Coorong region, South Australia. Sedimentary Geology 126: 147-157.

Zahn R, Schönfeld J, Kudrass HR, Park MH, Erlenkeuser H, Grootes PM. 1997. Thermohaline instability in the North Atlantic during meltwater events: stable isotope and ice-rafted detritus record from core SO75-26KL, Portuguese margin. Paleoceanography 12: 696710. 